\title{
NZ school librarians, technology leaders?
}

\author{
By Susan Clephane
}

School of Information Management, Victoria University of Wellington

Info 580 - Research Project

$\underline{\text { November } 2013}$ 


\section{Acknowledgements}

To all the school librarians who took part in this study - for sharing their knowledge, experience, opinions and most precious - time! My sincere thanks.

To my supervisor, Dr Philip Calvert, thank you for your guidance, encouragement and support.

To my Mum for all the cups of tea, to my Dad for trying to understand, and of course to Sean for proof reading my thousands of words and for putting up with me! 


\section{$\underline{\text { Table of Contents }}$}

Abstract 4

1 Research Problem 5

1.1 Rationale for the study 5

1.2 Research question $\quad 5$

2 Literature Review 6

2.1 Information Literacy 6

2.2 Know-how paired with infrastructure $\quad 7$

2.3 School Librarians as ICT leaders $\quad 7$

2.4 Definition 9

3 Method 9

3.1 Interview 9

3.2 Data Collection Method 9

3.3 Data Analysis 10

3.4 Limitations 10

3.5 Interview Considerations 10

3.6 Research Sampling 11

3.7 Control of Study 11

3.8 Ethical Considerations 11

3.9 Interview Questions 12

3.10 Human Ethics Committee 13

4 Results 13

4.1 Interview Process 13

4.2 Study Comments 13

4.3 General Background on Interviewees 13

4.4 School Libraries $\quad 14$

4.4.1 Helps $\quad 14$

4.4.2 Hindrances 15

4.5 ICT 16

4.5.1 Helps 16

4.5.2 Hindrances 18

4.6 Collegues/School Libraries 20

4.6.1 Helps 20

4.6.2 Hindrances 21

4.7 Leaders $\quad 21$

4.7.1 Helps 22

4.7.2 Hindrances 22

4.8 Future 23

5. Findings 23

6. Implications 24

7. Conclusion 25

8. Further Research 25

9. Bibliography 26

10. Appendices 28 


\section{Abstract:}

The purpose of this qualitative research study is to examine what role and views New Zealand school librarians currently have within their schools as technology leaders. At a time of technological developments in education, with both access to and implementation of ICT within school curriculums, what aids and hinders school librarian's position as a technology manager?

A variety of Auckland secondary schools were approached requesting a 30-60 minute interview with one of their librarians. Of the ones that agreed eight semi-structured interviews took place. The librarians were asked 14 open ended questions, some which were investigated further when necessary, and their answers were recorded, transcribed and results were drawn from their information.

My results found that the majority of librarians felt well supported by their colleagues. Each school, had its own distinct hierarchy that effected the way librarians conducted their jobs and the place they had. Most librarians felt that their role was not meant to be a "technology leader" per-say, but rather someone that would incorporate it within the library to make the library a useful resource. Some schools had specific positions for their librarians to partake in technology leadership. This made the library more of an ICT focus for the school. Overall the librarians all had a variety of experiences, mostly stemming from the hierarchical dynamics within the schools and their own education in the library field.

The implication for schools and their librarians, from this research may aid in considering the hierarchical set up their school currently has, how librarians view their role and what is a 'norm' versus alternative ideas. I think the discovery also reveals the various attitudes towards technology. This research may also increase awareness of the possible roles for school librarians in the future.

Keywords:

[secondary school libraries] [school librarians] [ICT] [leadership] [New Zealand] 


\section{Research problem:}

New Zealand schools are currently in a transitional period where technology is becoming a core aspect of the way they facilitate their duty - to provide their students with the skills they will need for the future. As many New Zealand schools have been embracing this, little research has been done toward investigating how the school's librarians are making themselves relevant as education transitions into an era where books are not the sole information resource for students.

\subsection{Rationale for the study:}

The purpose of the study was originally to examine the impact of the government's broadband roll out on school librarians. Since 2011 a five-year government initiative has been in place, to provide 97.7\% of New Zealand schools with the ability to access high speed internet. With $\$ 300$ million being invested in the roll out of the technology, the government has promoted the investment through improved educational outcomes for students, teachers and administrators. (Fiber to schools, fact sheet)

The question was: What happens after broadband has arrived at the schools? Who will 'take the reins?' Through past research it was evident that improved technology infrastructure cannot stand alone in improving user's usage, but must be paired with education so the new technological capabilities can be both understood, then utilized fully. (Alemanne, Mandel, McClure, 2011). School librarians hold a unique and pivotal position within schools as knowledge managers. School librarians potentially may play a major role in developing and promoting technology both at school and within their library.

What was quickly found, was the fact that Auckland schools already had ICT well integrated within their infrastructure and curriculum, and the Government initiative had not been a main incentive to installing this resource. Therefore the focus and rationale of this study is not simply to investigate the impact of the broadband roll out but to find out the position the school librarians now hold within their digitally able schools.

As stated by Johnston in her 2012 paper, 'School Librarians as Technology Integration Leaders: Enablers and barriers to leadership enactment.'

“...Despite the demands and opportunities for school librarians to accept this critical technologyintegration leadership role, this role is one that has been ignored in the research arena a lack theoretical foundation to guide enactment."

As both quality and access to ICT improve in New Zealand schools, there is a need to monitor the conditions school librarians are in to ensure best practice is promoted. This research has never been done in New Zealand before and aims to capture a snapshot of the attitudes and situations librarians are in.

\subsection{Research Question:}

This qualitative research study examines the role and views New Zealand school librarians currently have within their schools as technology leaders. At a time of technological developments in education, with both access to and implementation of ICT within school curriculums this 
research asks: What helps and hinders school librarian's position as technology leaders within their schools?

\section{Literature review:}

This literature review aims to establish the importance of Information Literacy and the factors that help and hinder a school librarian's ability to take on leadership roles, within New Zealand schools. By examining past studies that have investigated similar issues abroad we will begin to understand what has already been found. Along with this I aim to investigate recommendations made to improve the quality of a librarian's role within the school.

\subsection{Information Literacy}

The internet has become an integral part of everyday life for people around the world. It plays a role in the way we do business, the way we learn, communicate and govern; it has connected the world into an interdependent globalized community that does things faster and more efficiently than in times past. Information Literacy is the main component in lifelong learning. It aids people in becoming more effective problem solvers, especially in this heavily digitally geared society, (Fernandez-Villavicencio, 2010) and as Servon and Nelson describe; 'access to information technology (IT) and the ability to use it, increasingly become part of the toolkit necessary to participate and prosper in an information-based society.' (Sevron and Nelson, 2001)

This view, of ICTs being the way of the future, is commonly held around the world. It has become an expected way for people to participate - in both our personal and professional lives. Government's responsibilities have expanded to the web so that their citizens have the necessary tools to enable them to be competitive in the global market.

Overseas information literacy studies show that to impact people's abilities to communicate and progress, education must transition into a sphere where people do not simply consume information but also produce it. (McShane, 2011) The internet has become a global forum for business, socializing and education. If students do not have the know-how, to both use and produce on the web they will not be able to participate in the global market to its full extent.

NZ's fiber infrastructure, which is currently being implemented, intends to provide schools with the option to offer high quality internet access for their students. By offering the same access to our students as students overseas, our students will be on an equal par, and will hopefully be able to compete in the global market.

As a nation this initiative aims to address not only a digital divide with our overseas counter parts, but also within NZ, between urban and rural schools, higher decile and lower. By having the same option to access UFB, schools are equal, and a uniform standard will be possible. No child will be "left behind" and teachers will be able to prepare their students to navigate the web in the future. Schools are an integral part of the ICT development in NZ as they hold the position, not only educationally but financially, so that their students have the resources they need.

In 2007 the Manaiakalani project was set up. A cluster of schools (originally seven now eleven) in Tamaki, a lower socio economic area in Auckland's central eastern suburbs, got together to provide their students with e-learning. (Burt, 2010) The area is now fully wireless and an assessment in 2011-2012 showed an improvement of the student's reading levels. (Crown Fibre 
Holdings, 2013). This initiative has ensured that their students will not be disadvantaged and is used as a successful example for other NZ schools.

\section{$\underline{2.2 \text { Know-how paired with infrastructure }}$}

Even though the hardware is being implemented around New Zealand, it is only half of the battle. Unlike the film classic 'Field of Dreams', you cannot simply build a resource and have people use it; it will not be effective unless assisted by education. LaRose, Strover, Gregg, and Straubhaar's study of four US towns with new technology infrastructure (similar to New Zealand's) and found that the only place (Connecticut) where the fiber optic cable implementation was paired with education programs showed any major improvements to the public's ability to use computers. Though this study was based upon public libraries it still remains true to students. (LaRose, Strover, Gregg, and Straubhaar, 2011)

Other issues that have arisen are students' abilities to think critically. A focus group study on undergraduate students in the US found that while the students were quite familiar with social networking sites, their knowledge of possible education Web 2.0 resources, like bookmarking tools, was limited (Burhanna, Seeholzer, and Salem, 2009). Though this was a US study, it is a universal issue that unless a student is not specifically taking a web-based class they are not being provided with tools for assessing the information they find on the web for its quality and accuracy.

In a NZ Crown Fiber Holdings publication about the Manaiakalani project they found, "Often e-learning is seen as being about getting good download speeds from the internet... At Point England (local primary school) however, good upload speeds are just as important, as the teaching philosophy involves students creating something from their learning and uploading it to their blog, where it can be shared. Collaboration online is key - between students, and with their teachers and parents - and this will only work with a robust internet connection and good speeds". This was published in 2013, six years after the program initially began. It shows the importance of offering students not only the computer, but a teacher who is able to cohesively implement the curriculum into online platforms. (Crown Fiber Holdings, 2013)

As previously proven, schools cannot simply have fast broadband; they need to pair the resource with people that will teach, scan, organize and plan for its future. While teachers will be using the online tools they are under huge day-to-day pressures running their classes, it is not feasible for them to be able to keep up with all the new technologies. There is a need for someone to have sufficient professional development in ICT so they can support teachers with handy online resources and weave them into their lessons.

\subsection{School Librarians as ICT Leaders}

School Libraries have the potential be technology leaders within their schools. The style of management found in this past generation's librarians has been found to focus on "establishing positive relationships, creating flexible work environments, using technology effectively, and resolving conflict." (Estep, Tolley-Stokes, and Wallace, 2011). This paves the way for school librarians to adapt and create with their co-workers. 
In Johnson's 2012 research she points out the unique position teacher librarians hold within schools '... knowledge of pedagogical principles and curriculum, paired with technology and information expertise...' . This skill set, sets librarians apart from other staff and positions them, within schools, to lead collaborations between teachers and IT (Instructural Technologist) staff to provide students with current resources. Where teachers don't have the time, and IT staff don't have knowledge of the curriculum or teaching, librarians can take charge and be the one to investigate and develop new effective online educational resources eliminating the ambiguity of integrating technology within a class curriculum.

In the past school librarians have not been treated as equals to teachers (Sadowski and Meyer, 1993), despite many being university qualified as librarians. This inequality is shown through lower pay rates, funding cuts during recessions and small staff numbers. A Norwegian investigation into librarians' role and political influences concluded, "School librarians must be professional in both librarianship and education if they are to gain status in their schools. Principals and teachers, on the other hand, must know about the potential of the library for contributing to motivation and learning." (Elisabeth, Tove and Sundt, 2006). This shows the need for the highest professionalism to be brought by librarians to their jobs, and the need for respect and support by their colleagues.

Two similar studies, by Johnson and Smith, recently addressed this issue overseas and discovered some of the main barriers found were lack of confidence at using the technology, being unaware of the possibilities web-based learning could provide and lack of support from within the school. However through further reading these issues can be dealt with through education and support from the principal. The librarians need to want to use the technology and provide that leadership function within the school. If there is no interest, environmental scanning will not occur and the resource will have lost its value. (Johnson, 2012) (Smith, 2010)

The future role of librarians utilizing the technological possibilities is described in Dees, Mayer, Morin and Willis' article, 'Librarians as Leaders in Professional Learning Communities through Technology, Literacy, and Collaboration'. The article refers to a school in Georgia where the media specialists provide training days for the staff. What began as helping them to understand the basic uses of email, word processing, and Internet searches; evolved into modeling use of interactive whiteboards, incorporating wikis, and podcasting. From there they are able to monitor and measure which online resources are used most and by whom, and which are not used at all. This leads to further collaboration with the teachers by providing lesson ideas, resource suggestions and further collaboration opportunities to various teachers. The technology allows for more interaction and input with each teacher, and then as the source with which other teachers can gain new ideas and insight. (Dees, Mayer, Morin and Willis, 2010)

The majority of research in this area of study has been carried out in the US. It is a very progressive country in terms of school library advocacy as evident by the research. Here in New Zealand outreach is limited, many schools only have one or two full time librarians. Tools like the internet can be used to gain momentum into developing new resources and sharing ideas. We now have SLANZA (School Library Association of New Zealand) which provides a professional network. That paired with participating with online resources and research will develop information literacy among librarians, which will trickle down to teachers and then students.

As libraries hold a "knowledge manager" type position within their schools there is no reason why they could not take an ICT scanning, collaborative professional development role. This 
study aims to identify what is currently taking place in the libraries and what the librarians' views are of their position within an ICT context.

\subsection{Definitions}

Decile: level refers to the socio-economic rating scale (1-10) applied to New Zealand schools. Level 1 is the lowest socio-economic rating and level 10 the highest.

\section{Method}

The design of the project was as a qualitative analysis research study, though which school librarians would take part in a one-on-one, 30-60 minute semi-structured, recorded interview. This style of research was chosen as it allowed for exploration of views.

\section{$\underline{3.1 \text { Interview }}$}

Interviews were chosen due to their ability to yield a lot of information (Leedy, \& Ormrod, 2012). Interviews promoted discovery, due to it being face-to-face and one-on-one. It allows for subtleties the participant may reveal within human interaction. It also allows for the direction of the interview to be revised as new information emerges. Human experience is a valuable commodity that offers insight where surveys cannot. (Anderson, 2010)

\subsection{Data Collection Method}

Initially a variety of schools were selected as possible appropriate places to find interviewees. [Appenxdix E] These schools were then called and permission was requested from the principle to have access to their librarians. Emails were then sent to the principal or the principal's PA [See Appendix C]. From those that agreed (either verbally, by email or by forwarding the request to their librarian) the school librarians were then contacted by phone or email and were again asked whether or not if they would be interested in participating in the research study. The librarians were sent a Participant information sheet [See Appendix A]. Interview dates and times were then scheduled.

The interviews took place at the school's library (with one exception - the librarian was met at a café due to convenience). The school librarians were given a consent form [See Appendix B] preceding the interview and were explained that they would be emailed the transcript for them to check.

The interviews were recorded and lasted between 30-60 minutes. Fourteen open ended questions were asked, however the interviews were semi structured meaning some questions were answered in previous questions (so they did not need to be revisited) or some questions were explored more fully to get a comprehensive answer. This approach was chosen so the interview would have some direction whilst still giving the participant the opportunity to discuss information that may not have been considered by the study. 
It was decided that a focus group would not be necessary. Due the selection being of secondary school librarians, who are currently working, it is believed there is sufficient similarities to provide comparable data.

\section{$\underline{3.3 \text { Data Analysis }}$}

Following the interviews the recordings were transcribed then emailed to participants for checking. The transcriptions were a mixture of verbatim quotes and general points taken - depending on relevance. For example, the librarian's background was recorded generally whereas when the librarians discussed ICT within their libraries, or communication with other staff, exact quotes were recorded as this information was revealing and helped with accurate discovery.

The transcripts were then analyzed. The data collected was sorted and grouped according to themes and relevance, conclusions were then drawn from this information. A 'data analysis spiral' approach (Creswell, 2007) was used for sifting through the information gathered. By first 'organizing', then 'perusing' it - getting a feeling for themes and making notes, 'classifying' categories - now knowing the patterns grouping the information and finding insight, then finally 'synthesizing', drawing hypotheses.

This data aims to provide a broad picture of what school librarians are experiencing while focusing on what the librarian's views are.

\section{$\underline{\text { 3.4 Limitations }}$}

- Getting a representative normal distribution sample of New Zealand's secondary schools is difficult due to transport and time factors as well as a range being willing to participate. The results mean the study's findings may not be necessarily applicable to all school libraries around New Zealand.

- It is recognized that by asking both the Principal's permission and for the participants to volunteer for the study, it may draw out certain schools and librarian personalities that are "pro library development" and may have had significant experiences and ideas where as those that have declined may reveal alternate views and approaches that were not discovered during investigation.

- The participants interviewed may have had past experiences going through an interview process, resulting in those participants with less experience feeling inhibited.

- Interviews rely on the participant's memories as well as their subjective attitudes. For example the librarians might be quite tired and grumpy so their attitude on that day may not be completely consistent with their views under normal circumstances.

- This is the researcher's first time conducting a professional study. Interview skills will be improved over the course of the project, resulting in a variation in the reliability of each interview.

\section{$\underline{3.5 \text { Interview Considerations }}$}


During interviews it is important not to:

- lead the participant's answer

- $\quad$ react to their answers in a way that might effect what they are saying

\section{$\underline{3.6}$ Research Sampling}

It is understood that every New Zealand school library will have its own unique community and set up, which in turn will affect the way it utilizes the government initiative. As the nature of data is transient, this study will only provide a glimpse of what is occurring. However by selecting a range of libraries it was hoped that the results found will be replicable, and as time goes on and the libraries develop it will serve as a base from which further investigation may be sought.

The goal of this research is to gain an understanding of general trends and tendencies in the school, and to gain a realistic overview of what is occurring. The original list of schools asked to participate came from a mixture of backgrounds such as decile, location, size and ethnic groups. It is hoped through this approach that the study will achieve a broad overview of the general trends that are occurring.

\subsection{Control of the study:}

- $\quad$ Data was collected between September and October of 2013.

- The librarians were interviewed within a comfortable space and did not last longer than an hour.

- Discovery will be based around specific questions that will be asked of all sample members. If the answer has been volunteered earlier in the interview it will be at the researcher's discretion as whether or not to ask it again or divulge further into a topic.

- The interviews will be one-on-one.

- Interviews will be recorded using a Dictaphone so;

- Interviewer can concentrate on what is being said so answers can be followed up if necessary.

- Information is fully and accurately recorded so results are true.

- The sampling information used to select the schools was found through research using tools like NZ 2006 census data, the school's websites and other primary resources e.g. newspaper articles.

\section{$\underline{3.8 \text { Ethical considerations }}$}

- Interviews are optional for both the principal and school librarian.

- Demographical information collected is general: making it difficult to lead information back to the patron. 
- Libraries will be anonymous

- Interview participants can withdraw at any time before the discussion has begun until the beginning of November.

\subsection{Interview Questions}

1. Would you mind please telling me a bit about your background as a school librarian? Both at this school and elsewhere? Jobs? Qualifications? Do you have any ICT training? Do you hold any leadership roles at your school?

2. How do you keep up with day to day learning developments? (information diet) Do you have much contact with outside library organizations such as SLANZA or LIANZA, or other librarians?

3. Bit of background on the school and library? How many library staff? Do you teach?

4. Do you know much about the government's current broadband roll out and how it is going to be affecting your school? Do you have someone keeping everyone up to date?

5. How much are ICTs a part of your school and your library? Is it incorporated as a part of the curriculum? If so what and how is used?

6. Does your school put much focus on using ICTs? How? Have you seen any benefits if students are using them?

7. Where would you rate your computer competency between 1-10: 1 being beginner and 10 being an expert? And in comparison are the students, in your view competent users of the internet?

8. What are some hindrances that you find to using IT? Do you have all the equipment? Do you have the time/resources to learn more?

9. What do you think about web based education tools? How helpful are they for students and staff?

10. When it comes to ICTs in your school, who do you consider are the main drivers/leaders within the school? And Why?

11. Could you please describe how much support, encouragement and collaboration do you have with your co-workers? ...from teachers, ICT staff and principal?

12. What do you see as barriers in the way your colleges can and do support, encourage and collaborate? E.g. organizational reporting structure, personalities that don't gel? 
13. Are there opportunities to become a leader within the school? What helps this? And if not what do you think are the main issues hindering this?

14. How do you view your role as a school librarian in the future? Do you see yourself as someone who may aid in implementing online resources more for both students and teachers? Do you think there are any things that might help or hinder your ability to be an ICT leader in the school?

\subsection{Human Ethics Committee}

Approval by Victoria University of Wellington's Human Ethics Committee, for this research project, was granted on the $19^{\text {th }}$ of July 2013.

\section{Results}

From the eight interviews that took place during the course of investigation many similarities and differences were found in what helps and hinders school librarians do their job and be a valuable resource to the school.

\section{$\underline{4.1 \text { Interview Process }}$}

Of the librarians interviewed all eight were from secondary schools, which had students between the years 9-13. These schools also had a range of ethnic groups and were within the Auckland region. For gender, decile and student population [See Appendix D] (NZ School, 2013)

It was quite a difficult process trying to get interviews. Though a range of schools were initially asked, due to time and distance restrictions, such a broad range of interviewees was not eventually used and the study mostly focused on higher decile schools [See Appendix D]. It was found that lower decile schools approached were either not responsive (did not reply to emails and could not be contacted by phone) or declined to participate. It had been hoped the participants would come from a diverse range however discovery was still to be had, and it was found by the end of collecting the data, as there were a lot of repetition of answers.

\subsection{Study Comments:}

- I had issues with the Dictaphone during an interview. After recording what I could I sent the librarian what I had recorded and they added to it as they saw fit. Also during one of my interviews the man in charge of ICT popped in and gave me some additional background and planning for ICT at the school.

- This study is limited to Auckland urban schools. According to an ICT specialist within one of the schools interviewed Central Auckland was low down in the priority list of improving their broadband. Next year there are plans to increase the data cap, for those that do not have fiber optics, so schools will be able to afford to implement ICT resources like BYOD.

- Since beginning this project in Dec 2012 I have noticed the amount of information about UFB for schools has increased, both on the Chorus website and Ministry of Education. This may be because many of the cables have been laid and schools are now looking to upgrade. 
However the actual educational benefits and professional development support have not been paired. It seems that schools are expected to organize this aspect themselves.

\section{$\underline{4.3 \text { General Background on Interviewees }}$}

Of the eight librarians interviewed:

- $\quad$ Four were library managers and four were full time librarians.

- $\quad$ All of the librarians had over five years of experience working in libraries.

- There was a range of qualifications and training - from those that had an MLIS degree to those that take online classes and attend National Library seminars.

- All librarians said that they tried to keep up with what was going on among libraries - the most popular being reading things from the list-serve, going to SLANZA conferences and reading library blogs - this was also something that was constrained to time.

- There was a range of computer competency - from those that ran programs and developed helpful online resources for classes to those that left the IT responsibilities to other librarians. All participants understood their catalogue system and were comfortable with online searches.

- The majority of libraries had at least 2 full time librarians - the amount of librarians correlate with the size of the school.

- Every school had their own unique hierarchy depending on the size and focus of the school.

The information below has been synthesized into common themes discussed by the participants during the interviews. Some quotations have been included where appropriate. The data collected reveals their views have been created through real life situations, with precautions taken to not reveal the identity of the librarian or the secondary school.

\section{$\underline{4.4 \text { School Libraries }}$}

- All of the libraries were used for classes during the day. The libraries often opened earlier and closed later than normal school hours.

- $\quad$ All of the libraries had computers.

- All the librarians commented on the high usage and user satisfaction of the pupils.

- Consistently, librarians commented on student's lack of critical thinking when it came to assessing resources and using internet sites.

- $\quad$ All schools were wireless: some to a higher standard than others (bandwidth, speed, etc.)

\section{Is the library valued by the school?}

For librarians to be leaders they need to be a contributing and used asset. All of the libraries reported high user rates. Both from classes constantly booking space, to students enjoying using it in their fee periods and lunch. When visiting and observing the libraries during the interview they appeared to be busy. The librarians interviewed had a variety of ways they ensured this as well as what made it difficult. 


\section{$\underline{4.4 .1 \text { Helps }}$}

"We say, 'interrupt us', and we are interrupted all day"

Spaces: All of the school's libraries had areas within them for classes to book (some for the computers, some for research.). One librarian spoke about many different school groups booking the space for meetings.

Events: Libraries put on events such as reading month, or hosted morning teas with various departments.

Morning Teas: Some libraries conducted outreach to the teachers by either putting on morning teas for departments or making sure they could go to the staff room during break times. The ones that did not provide this outreach seemed to be a little bit more disconnected with the staff at their schools.

Relationships: at three of the schools, having meaningful conversations and relationships were explicitly stated as very important.

- All of the schools had some form of a student librarian program. These ranged from students helping with shelving, to full programs with points for writing on the blog and official meetings.

- One librarian mentioned the importance of being aware of when the teachers were under a lot of stress and not asking anything of them until busy periods (like exams) had passed.

- Working with teachers: One librarian discussed the usefulness of "Specific talk of a specific topic". After the teacher had brought their class in with a project the librarians would use a targeted approach, breaking down the project into workable context, "here is a pressie that is available later, here are some resources, this is what I think you should try, this database, use this process, think about it in this way". She found by integrating the libraries' resources into a project, "students feel far more confident and they are moving forward better. The teachers think I'm doing okay."

\subsubsection{Hinderences}

"I think we could defiantly do more. We probably would need more library hours."

Resources: Seven of the eight librarians mentioned their wish for the library to have either
a full class set of computers
a screen to play book trailers
better photocopying and printing machine
class set of portable devices

(The librarians who mentioned these were making plans in their future budgets to include the items.)

Rules: This issue seemed to come down to a personality and attitude. One librarian mentioned; "Different people's ideas of what a library is and what is important. For me and other teachers it is 
more important that the kids read books than that they carry their library cards." This comment I believe shows that within a library staff there could be perhaps a lack of understanding both of students, and learning, hindering the students' comfort with approaching librarians.

Pay rates: Five of the eight librarians mentioned issues with pay rates. As school librarians are considered support staff by the ministry, they are not paid like teachers. The librarians discussing this issue said it resulted in frustration (with their job) and also believed that it reduced the interest in the position for future talented librarians.

Interest: Four of the eight librarians commented on the major issue of their colleagues not being aware or understanding what the library could provide for them and their students.

\section{$\underline{4.5 \text { ICT }}$}

Of the eight schools interviewed:

- Seven of the secondary schools were either BYOD (Bring your own device) or in the process of rolling it out for next year.

- All of the schools had wireless connections either throughout the whole school or in "hot spots".

- Most libraries had online catalogues, some had blogs, and some had e-books.

- $\quad$ All eight said ICT is heavily used by their students.

- The majority of ICT decisions for the schools were made by the ICT committees - heading by a Deputy Principal or Head of IT (different titles, same job) or the school's principal.

- Seven of the eight librarians interviewed were unaware of when and how the broadband roll out would affect their school.

- Being Auckland schools, with average connectivity, they are not seen as high priority by the government.

- Of the eight librarians interviewed only one of them had an official "ICT" role title

\section{What helps and hinders ICT at the schools?}

\section{$\underline{4.5 .1 \text { Helps }}$}

Digital Resources: IT among all eight libraries, was interwoven through the services they provide, their learning and day-to-day lives. The librarians that were integrating these resources within the services they offered talked about the positive feedback from both students and teachers. It seemed like the libraries where this happened were really supporting the teachers in a way that made their job easier and aided students in preparing for projects as well as for university. The extent of the research the students conducted would not be feasible with only books.

"I think in every encounter we have with a student we are using IT, whether we are searching or they are searching, and I think when they come down to do research it is not books or internet it is both." 
- "The hugest improvement has been the increase of digital accessibility created by National Library, Papers Past, Digital NZ, all those Primary sources are now easily available to students, because of course they are part of our homepage bundles, so that focus that the curriculum has, not only on doing research but doing research using primary documents, they are getting better used to content online."

- Web-based learning tools: "I've been using curation tools such as scoop it and livebinders and that has made a huge difference how a class does a research unit. So traditionally they would come in here and we would do a box full of books for them. We still do that. But I say I will do a scoop it on all the websites that suit your study criteria. And put that together then I can send the teacher the link and the students can all use the link. I only choose the sites we know are really good. I can point them in the direction of National Library and Te Ara and all those places they can't seem to find just by Googling."

- One of the libraries, where the school was more IT focused found that Google Docs has been a really useful and easy resource that has encouraged both teachers and students to use the cloud-based educational tool.

- Some libraries either had or wanted screens so they could show Book Trailers and promote library resources. This resource, though not necessary in the day to day running of the library helps with promotion.

"Gently, gently approach": With all the new technologies becoming available not only within the schools but also within the libraries one librarian commented on not forcing the technology on teachers. To let them "see where the benefits show themselves."

Professional development: Seven of the librarians were quite conscious of "keeping up" with the ICT developments going on (the other one said she didn't consciously make an effort to do this however she was well qualified in IT). Three of the librarians discussed classes they had taken and how it had helped them in their libraries do things like, create displays, utilizes databases and their catalogue more efficiently and communicate with students more effectively.

ICT committee: Four libraries had a librarian on their schools ICT committee. This increased the librarian's involvement within the school and worked as a flagship for the library in the IT sphere.

IT Staff: All librarians commented on the quality or helpfulness of the ICT staff.

"Sometimes they do have that look on their faces, but they don't say anything, they just say ok, alright, or they might say "why do you do that" and I'll explain what I'm using it for and then they'll get it." - referring to IT staff not always understanding why the librarian wanted to do what they wanted to do, but once it was explained it was not an issue."

Digital Literacy: "It is terrifying how many kids still copy and paste, and don't even recognize that that is not their own work." It was unanimous among the participants commenting on student's lack of critical thinking of web based resources. Various libraries combated this in different ways; 
- Classes (Four libraries will offer to talk to students when their teacher books to use the library, one of those librarians has also set up a digital literacy class as part of their curriculum).

- Set tasks that require a high level of processing, searching in a smart way and then feed it out through departments.

- Promote "Many Answers"

"Can do" attitude: "I don't know a lot about the background of technology and how it works. But I have learnt that anyone can pick up the web tools that are available on the internet. And it is easy. Getting your head about those tools...it is doable. You don't need to be an IT expert to work out any of those things. You just have to have a wiliness to try new things." Only one of the librarians had any extensive IT training, however this did not seem to stop any of them from attempting to learn how to use new resources.

BYOD: There were a mixture of responses to BYOD. Some schools had only recently rolled it out and they were still waiting for evidence of how it was going. One librarian however, that came from a school where the students were well integrated in BYOD commented on it by saying how the students were, "tech whizzes", and they in some ways knew a lot more about computers, though they also commented on the students lack of critical thinking when it came to sites.

\subsubsection{Hindrances}

"If you are bombarding teachers \& students with web tools too frequently, they get overwhelmed. Many of the tools do similar tasks (Evernote, Diigo, livebinders \& other web clipping tools) I think it is important to focus on a few and find a niche for student use and access."

Time: All the librarians commented on never having enough time to do everything they want to do with their libraries, the main thing being environmental scanning.

"There never seems to be enough time to learn more. Just in time learning - seems to be how it goes for me - a situation arises and I will want to use a certain web tool and I will then concentrate time on getting to grips with it. There is so much educational reading to do too - all very helpful...More than one can possibly keep up with."

- This was also mentioned of the IT staff. At some schools the IT department was sufficient, but at others - that were BYOD, the IT department was not able to always respond to troubleshooting issues quickly - reducing the libraries ability to help students and teachers.

One-stop-shop? Some librarians commented on the attitudes of both students and teachers being only internet focused when it came to researching.

- "The kids will go to that (internet) first, and we have to try and stop our teachers sending the kids to that first, for doing research. We encourage them to use the book collection and get to know it." 
○ "They think the internet has all the answers. They get extremely frustrated and upset when they discover what they need to know isn't there. So as librarians we have to help them navigate those "treacherous rocks". I think one of the biggest problems occurred when Google became a verb."

Space: "We have physical space issues, if we could squeeze a few more computers in I would really love to have a whole class set." As previously mentioned libraries host classes doing research, however computers take up space and need to be accommodated for. With libraries having to balance their shelving with computers this can be difficult for some schools. Three librarians discussed e-readers being a useful tool, which would reduce pressure on space, other librarians had plans on dramatically reducing their non-fiction and using data-bases and websites for the information instead.

Financial: Computers, portable devices, screens, databases, broadband speed, infrastructure and bandwidth do not come cheaply. This was a stated barrier for all of the schools.

“...you know can't have it all right now, year after year you have to focus on different areas,"

- In one particular case the school found a real barrier dealing with the government run broadband roll out group who did not understand the situation correctly and would not allow them a cheaper offer.

Tradition: Most of the schools interviewed did not have this issue, however two of the schools were quite traditional. One of the librarians commented that the school had very specific approaches to teaching styles and would not convert as quickly to IT integration as other schools. (This school was still using IT, however it was not as integrated as other schools)

Troubleshooting: Three of the librarians talked about the issue of having to deal with devices not working, not being charged, having to navigate logins and Wifi. This, they said would put pressure on them, teachers and IT staff, reducing the actual time spent working. Issues like this I believe would be ironed out as the schools become more integrated.

"I think it (IT use in school) has been hampered by slow broadband. We want to be doing things now - even teaching in class rooms - that we can't because of the slow internet.

Timewasting: A few of the librarians commented on students using the computers for games and social media.

Communication: In two cases I found the communication between the libraries staff about ICTs at the school and within the library was lacking. The librarians were not aware of what planning was being done or had not been kept up-to-date with ICT at the school. This seemed to be due to the librarian's view that that area was not a part of their responsibility - not in a negligent way but rather that others were more appropriate for the job. I believe this stemmed from the personalities of the librarians. Other libraries seemed to prevent this by having set times in their schedule to sit down and discuss with their co-workers.

Rules: "I'd say rules and IT rules and restraints, like blocking websites and kids not being able to access things, I guess security issues." 
Knowledge of the Curriculum: A couple of the librarians did not have significant knowledge of what the students were learning, how they were learning or have much contact with the teachers. They focused on their job contained to the library. I got the impression this was due to

a) The library being busy with the day-to-day operations, so there was not the chance for outreach.

b) Teachers not being aware of the support librarians could provide and therefore not taking action in getting it.

c) The librarian believing online searching skills are the responsibility of the teachers.

\section{$\underline{4.6 \text { Colleagues - School hierarchy }}$}

It was apparent at every interview I conducted that each school had its own unique hierarchy. As with most organizations this is fostered by structure, personalities and rules and size. It was evident that the way each place was set up affected not only the way the library could be run but the chance and willingness of the librarians to take on a leadership role.

\section{What creates rigid school hierarchies? And what breaks them down?}

\subsubsection{Helps}

Qualifications: "They were very complementary about me from the start so I think because I had a qualification it really was an advantage...to have a decent qualification rather than a diploma or something like that so they respect me as a professional."

Fresh Perspective: Some of the librarians commented on those that had preceded them in the role at the school and how they had left a legacy that had not enticed teachers to the library. Since they were new they had been able to mix up the way the library ran. "I think coming in fresh from somewhere helps, in a lot of ways, you come in and I already had the ideas of what I wanted to achieve and they have been very receptive to what I offered. And then when they saw that it was beneficial to them they embraced the changes."

Personality cohesion: If the personalities of the teachers and librarians meshed well together it created better team cohesion between the two.

- Within the library (as well as the school) there is a place for hierarchy - if there is a manager, part-time staff etc. To prevent this one librarian said: "We are always talking, always bouncing new ideas around and getting things done. I know that every team needs a leader, but we are not a hugely hierarchical place, because I think we do work fantastically, I do want everyone's ideas."

Principal: One librarian commented that the school's positive culture was set by the principal, this seemed to echo through other interviews where librarians described their principals being "prolibrary". When the principals set a library friendly standard and showed support, it seemed to effect the culture of the school and the librarians felt more inclined to speak up. 
Budget: Five of the librarians commented on their budgets being left alone, and how they felt that was really good support, and showing they (principal and board) saw value in the library.

Conversations with Staff: "I have found the best way (getting people on the side of the library) is by making friends and making the conversations in the staff room. Without that we would have to stand up and do a presentation."

Quality of service: "I think that people when they do come down and use the library, and we are given the notice, and they tell us what they want, they have been really pleased."

Support: One of the key approaches the librarians had was to try their best to support the other departments.

- "I do quite a bit of the troubleshooting for IT in the library, sort out the wireless connection. So I support them, I do what I can to a certain level, if it isn't working they know it is something more, and they are good at coming. And there is a good system you can report it via and email system, so it is well managed."

- "If I can possibly do it I say yes to everyone. For space, or resources. We have a good budget sand if teachers have a particular request I do my upmost to find it. So being helpful and friendly and supportive of what they are trying to do, you get the same back. It is reciprocated. So I think I am really well supported by the staff in the school."

- "Being aware of the stresses that the teachers are under at the moment, and so being supportive of that, and not dumping something on them that is too difficult."

\section{$\underline{\text { Hindrances }}$}

System Structure: Due to the tier system of promotion within schools, one of the interviewees was unable to be promoted. This meant that the librarian would not get the chance to be a manager resulting in less access and decisions being able to be made within the library.

Contact with Principal: At nearly all the schools the librarians had little to no contact with their principal. Communication was usually done through deputy principals. There were a few librarians that had more contact with the principal and they seemed to be more inclined to pushing new ICTs forward for the school. As principals were stated as one of the main reasons ICT was pushed through the school, it can be said the communication between the principal and librarians is very important.

Size: Getting to all of the staff in the bigger schools seemed to be a barrier - volume of people vs small staff of libraries.

Attitude: "It really depends on the attitude of the teacher. People will get what they will out of us. If they are willing to use us. If they are going to use us they find it really good, otherwise really it is there loss. We try to promote what we do, and use teachers who have used us to talk to other staff."

\section{$\underline{4.7 \text { Leaders }}$}

Seven of the eight librarians did not view themselves as ICT leaders within their school. Why? 
- Because their school already had IT experts fulfilling this position

- $\quad$ Because they did not feel it was part of their position

- Perhaps because they felt under qualified

"I wouldn't see it as my role as being the IT leader in the school, information related things, yes, I would hope the library would be seen as leading in that, and we aim to be, with the databases and information type things but just general no, we have specialists. In some school librarians have been asked to look after the network and this that and the next thing, and to me that is not right, often that gets some big it stops them from being a librarians. In one National Library document it was sort of said, perhaps that was a good thing, but in fact in raising the profile of librarians, but wasn't, it was raising the profile of them as a network manager. I think librarians need to strive to have the profile seen as librarians I think they are two different roles."

This does not mean that they are not ICT leaders however. Despite not seeing themselves in a leadership role because they are not making school wide decisions does not mean they are not leading.

\subsubsection{Helps}

Teach: The librarians that commented the most on how positive the teachers were towards them and how much they were used were the ones that were creating web-based research aids - along with the normal responsibilities. They were the ones teaching the students critical thinking and scanning for new and helpful sites and tools.

"One of the things I do with the talk I give, I show them some strategies to refine their searches, and they are very interested in that, how to change it to only an educational website, just little tips and tricks about Google, that kind of opens them up and they think "oh That's cool." Just as opening them up to other kinds of search engine."

"Putting yourself out there, being the face of the library, is really important."

"Teach the teachers to do something and then get them to teach the kids and the librarians will supporting the kids when they are using IT in the library."

Professionalism: One of the librarians commented on the respect she got, and the fact people listened to her being tied to her qualification and professionalism. "Some people just presume all librarians are unqualified. So they knew I'd been chosen because I professionally had the qualifications."

\subsubsection{Hindrances}

Complacency: While all the librarians seemed to enjoy their jobs, two of the interviewees seemed to have simply accepted their role and did not really consider pushing for more responsibility. They had accepted the school structure and bought into their place within it.

"No particular opportunities (leadership). People are in certain roles and it seems to stay like this." 
Confidence: Seven of the librarians rated themselves either six or seven in terms of ICT capabilities. They were aware they did not know everything. This could possibly be linked back to them not wanting to be ICT leaders - not knowing enough about the hardware and software available and what would be most appropriate.

\section{Structure:}

- One of the librarians said that though they feel like their opinions were valued, the structure has already been set in the school and there is not a position for her as a leader.

- Three of the librarians did not believe being an ICT leader was their job. "Because you are a librarian, doesn't mean to say you are an IT expert that can run a network, and it shouldn't be seen as less of a librarian because you aren't do someone else's job."

\section{$\underline{4.8 \text { Future }}$}

"We have to move, we have to evolve."

The librarians were asked, in their view, what was the future of school libraries and their role in it. With the internet providing so much information it is possible that some may view the library as an obsolete feature - especially if the library has not adapted to the new technologies and ways of learning. The majority of the responses were positive in terms of there being a need for a library - "I think you there will always be a need for people to need this sanctum. Give them e-books, but they will need this place to be."

All of the librarians predicted huge changes to the library - both through swapping ebooks for physical books and how the library would be used. Two librarians discussed the 'modern learning environment' and how that may be a great approach to setting up the library for students, to allow collaboration and IT. "I believe the future of libraries is part of the school, not just your place, not just your library that you can move anywhere, be anywhere with your online stuff."

\section{Findings}

What helps and hinders school librarians' position as technology leaders within their schools?

The four leading points that effected librarians' position as technology leader came back to resources, attitudes and structure.

Resources: This is broad and ranges from time, to hardware and software, high speed internet and space. The librarians, each depending on their circumstances, discussed the need for them to have these things to provide quality services for their students. For preparation and presentation of ICT the librarians need the support of quality resources so they can create an ICT space that is used and looked to for guidance. 
Attitudes: Librarians discussed creating and maintaining healthy relationships with their colleagues - by talking to them about what they need and what the library needs in a thoughtful way (i.e. not during exam time). Some librarians also felt the most effective way of creating positive attitudes towards librarians was through providing supportive web-based tools, discussing with IT staff why they are doing what they are doing, and being recognized as a professional (through equal pay). It was recognized that some personalities were not cohesive and that was a hindrance.

Structure: The main influences on whether or not librarians felt they could be ICT leaders came from support by their principal and the approach the school had towards education - traditional vs modern. The principal was said to set the standard for the school - if they were pro library the librarians seemed to feel more able to carry out programs and get involved in ICT related subjects. In the more traditional schools they had a more rigid structure where people stayed in the same roles for their life and it was difficult to change views along with the school not willing to take up digitally focused resources as quickly as some.

The two leading reasons that seemed to either hold back or enable a librarian to be leaders were:

- $\quad$ Support from the principal and those in higher management positions

- The librarian keeping up-to-date and actually creating programs and putting web-based educational tools to use for the teachers.

The support enabled librarians: to purchase hardware and software, participate in the planning of ICT within the school and therefore encourage them to become more ICT literate, get professional development training so they could offer support to other teachers and students. This support translates to the students having access to high quality resources and encourages the librarians to take risks and attempt to grow their role.

The librarians taking an active role in implementing ICT within their library through classes: keeps them up-to-date with what is going on in the digital world, impresses both teachers and students so they know how useful their librarian can be, and marks out their place within the school - enabling them to have a say about the infrastructure and resources the school needs.

\section{Implications}

The implications for this research is that it highlights the importance of both support from the leaders in the schools as well as school librarians being proactive in their approach to their job. Using the internet to their advantage, creating new web based tools, making themselves indispensable as an environmental scanner, a knowledge manager and supporter of teachers and students.

This study also highlights issues of complacency. The importance of remaining enthusiastic about learning seems imperative to providing a quality service. When a librarian would not take the initiative to push themselves the library would be the thing to suffer. This may mean that librarians need more of an opportunity to be enthused. I believe organizations like SLANZA and library blogs can do this for librarians. It is therefore important that librarians are encouraged, by their school to partake in these collaborative meeting of minds.

While the hierarchical structure is partly to blame in librarians not feeling like they can be ICT leaders, this is a difficult thing to combat. It comes from tradition, the principal and various 
personalities within the staff. While a librarian may not be able to get themselves onto the ICT committee they should be aware that does not mean they cannot be leaders and find their own ICT niche within their schools. Librarians in this study discussed paving a way for themselves by creating useful resources and establishing quality relationships. What is implied is that though some librarians did not view themselves as leaders, through listening to the work they did, both teaching and personal learning I have to beg to differ. A leader does not always lead by telling people what to do but sometimes rather by guiding people and supporting them.

\section{Conclusion}

There is a huge quantity of rich information within the results above. The personalities of the librarians, along with the schools' unique make-up leads to every case being unique and it is understood that these are purely subjective views. However through the interview process a number of similarities were established by the librarians in what helps and hinders them in their role. From resources, to communication, attitudes and structure, each librarian had their own hurdles as well as support in providing quality service for both students and teachers.

What was found from all eight of the interviews was a positive approach to the job. There was a variety of experience between the librarians and they were all at different points in their careers, but the overarching job satisfaction seemed to be apparent.

\section{Further Research}

Research could be done looking at:

- A larger sample of librarians in a quantitative format. This would give a fuller picture of what is going on for school librarians.

- The value of having librarians in technological roles - how it helps/hinders teachers and/or students. This would be more specific and would be done as a comparison between a school that has fully immersed its curriculum using ICT vs a school that is still using a more traditional style of education. This would give insight into the benefits of educational ICTs.

- Collect the views of principals, teachers and ICT staff throughout NZ schools regarding the value of school libraries. This study was purely based on school librarian's views. It would be interesting to discover the views from the other areas of the school.

- How much being a qualified librarian matters to the quality of the library. Qualification and professional development (PD) seemed to give some librarians an advantage among teachers in terms of respect for them as professionals - as well as PD keeping librarian's interest in their job alive. It would be interesting to observe the advantages. 


\section{Bibliography}

Alemanne, N. D. Mandel, L. H. and McClure, C. R. (2011). The rural public library as leader in community broadband services. Library Technology Reports, 47(6), 19+ Retrieved from http://go.galegroup.com.helicon.vuw.ac.nz/ps/i.do?id=GALE\%7CA266941496\&v=2.1\&u=vuw\&it=r $\underline{\mathrm{p}}=\mathrm{AONE} \& \mathrm{sw}=\mathrm{w}$

Anderson, C. (2010). Presenting and Evaluating qualitative research. American Journal of Pharmaceutical Education, 72(8). Retrieved from http://www.ncbi.nlm.nih.gov/pmc/articles/PMC2987281/

Branch-Mueller, J. and de Groot, J. (2011). The power of web 2.0: Teacher-librarians become school technology leaders. School Libraries Worldwide, 17(2), 25-40. Retrieved from http://search.proquest.com/docview/903778312?accountid=14782

Bush, G. (2006). The Changing Role of the School Librarian. Principal, 85(4), 56-58.

Burhanna, K. J. Seeholzer, J. and Salem, J. (2009). No natives here: A focus group study of student perceptions of web 2.0 and the academic library. The Journal of Academic Librarianship, 35(9), 23532. Retrieved from Science Direct database.

Burt, R. (2010, July). Project background [Fact sheet]. Retrieved October 31, 2013, from http://www.manaiakalani.org/home/project-overview

Creswell, J. W (2007) Qualitative inquiry and research design: Choosing among five approaches (2.d. ed.) Thousand Oaks, CA: Sage

Crown Fibre Holdings. (2013, July 15). Manaiakalani role models. Retrieved October 31, 2013, from http://www.crownfibre.govt.nz/2013/07/ultra-fast-broadband-is-the-latest-piece-in-atechnology-puzzle-that-has-seen-a-low-decile-auckland-primary-and-its-neighbouring-schoolsbecome-role-models-for-e-learning-in-new-zealand/

Dees, D., Mayer, A, Morin, H, and Willis, E. (2010). Librarians as leaders in professional learning communities through technology, literacy, and collaboration. Library Media Connection, 29(2), 1013.

Elisabeth, T. R. Tove, P. S. and Sundt, E. (2006). Norwegian policy: Empowering school libraries. School Libraries Worldwide, 12(1), 50-58. Retrieved from http://search.proquest.com/docview/217752296?accountid=14782

Everhart, N., Mardis, M. A, Ed D, and Johnston, M. (2010). The leadership role of the teacher librarian in technology integration: Early results of a survey of highly certified teacher librarians in the United States. International Association of School Librarianship. Selected Papers from the Annual Conference. Retrieved from http://search.proquest.com/docview/821698365?accountid=14782

Estep, E. Tolley-Stokes, R. and Wallace, M. (2011). The generation x librarian : Essays on leadership, technology, pop culture, social responsibility and professional identity. Jefferson, N.C. McFarland and Co. 
Fernandez-Villavicencio, N. (2010). Helping students become literate in a digital, networking-based society: A literature review and discussion. International Information \& Library Review, 42(2), 124136. doi:10.1016/j.iilr.2010.04.012

Fibre to schools [Fact sheet]. (n.d.). Retrieved May 14, 2013, from http://www.chorus.co.nz/fibreto-schools

Hanson-Baldauf, D. and Hughes Hassell S. (2009). The information and communication technology competencies of students enrolled in school library media certification programs. Library \& Information Science Research, 31(1), 3-11. Retrieved from ScienceDirect database.

Johnston, M. P. (2012). Connecting teacher librarians for technology integration leadership. School Libraries Worldwide, 18(1), 18-33. Retrieved from

http://search.proquest.com/docview/921332140?accountid=14782

Johnston, M. P. (2012). School librarians as technology integration leaders: enablers and barriers to leadership enactment. School Library Research, 151-33.

Kachel, D. E. and Lance, K. C. (2013). Librarian required: a new study shows that a full-time school librarian makes a critical difference in boosting student achievement. School Library Journal, 28.

Retrieved from

http://go.galegroup.com.helicon.vuw.ac.nz/ps/i.do?id=GALE\%7CA321335241\&v=2.1\&u=vuw\&it=r $\underline{\mathrm{sp}=\mathrm{AONE} \& \mathrm{SW}=\mathrm{w}}$

LaRose, R., Strover, S, Gregg, J. L. and Straubhaar, J. (2011, January). The impact of rural broadband development: Lessons from a natural field experiment. Government Information Quarterly, 28(1), 91-100. Retrieved from http://dx.doi.org/10.1016/i.giq.2009.12.013

Leedy, P. D. and Ormrod, J. E. (2012). Practical research - planning and design (10th ed.). Pearson. Levine, J. (2006). Case studies: School libraries. Library Technology Reports, 42(5), 31-37. Retrieved from http://search.proquest.com/docview/202708731?accountid=14782

Lingard, L. Albert, M., and Levinson, W. (2008). Qualitative research: Grounded theory, mixed methods, and action research. BMJ: British Medical Journal, 337(7667), 459-461. Retrieved from http://www.jstor.org/stable/20510644

Loertscher, D. (2003). The digital school library: A world-wide development and a fascinating challenge. Teacher Librarian, 30(5), 14-24. Retrieved from

http://search.proquest.com/docview/224878677?accountid=14782

McShane, I. (2011). Public libraries, digital literacy and participatory culture. Discourse: Studies in the cultural politics of education, 32(3), 383-397. doi:10.1080/01596306.2011.573254

NZ Schools. (2013, July 8). New Zealand schools - Directories (Ministry of Education \& Statistics NZ, Ed.). Retrieved November 6, 2013, from http://www.educationcounts.govt.nz/directories/list-of$\underline{\text { nz-schools }}$

New Zealand Ministry of Education. (n.d.). Ultra-fast broadband frequently asked questions. Retrieved October 31, 2013, from 
http://www.minedu.govt.nz/theMinistry/EducationInitiatives/UFBInSchools/QuestionsAndAnswe $\underline{\text { rs/UltraFastBroadband.aspx }}$

Sadowski, M. and Meyer, R. (1993). States of inequality. School Library Journal, 39(6), 34.

Servon, L. J. and Nelson, M. K. (2001), Community technology centers: Narrowing the digital divide in low-income, urban communities. Journal of Urban Affairs, 23: 279-290. doi: 10.1111/0735-

2166.00089

Smith, D. (2010). Making the case for the leadership role of school librarians in technology integration. Library Hi Tech, 28(4), 617-631. DOI10.1108/07378831011096277

\section{APPEDICIES:}




\title{
Appendix A:
}

\author{
SCHOOL OF INFORMATION MANAGEMENT \\ TE KURA TIAKI, WHAKAWHITI KŌRERO \\ LEVEL 5, RUTHERFORD HOUSE, PIPITEA CAMPUS, 23 LAMBTON QUAY, WELLINGTON \\ PO Box 600 , Wellington 6140 , New Zealand \\ Phone + 64-4-4635103 Fax +64-4-4635446 Email sim@vuw.ac.nz Website www.victoria.ac.nz/sim
}

\section{Participant Information Sheet}

\author{
Research Project Title: New Zealand School Libraries Uptake of High Speed Internet
}

Researcher: Suzy Clephane, School of Information Management, Victoria University of Wellington

As part of the completion of my Master of Information Studies, this research study is designed to benefit both current and future school communities promoting awareness of how to best use and support school librarians as technology communicators within schools. I aim to identify what the current situation is in schools where high speed internet is relatively new to both the staff and students, and what is being done to educate and promote the new capabilities high speed internet provides.

Victoria University requires, and has granted, approval from the School's Human Ethics Committee.

I am inviting school librarians to participate in this research. Participants will be asked to take part in a 30-60min interview. Permission will be asked to record the interview, and a transcript of the interview will be sent to participants for checking.

Participation is voluntary, and you or your school will not be identified personally in any written report produced as a result of this research, including possible publication in academic conferences and journals. All material collected will be kept confidential, and will be viewed only by myself and my supervisor Dr Philip Calvert, Senior Lecturer School of Information Management.

The research report will be submitted for marking to the School of Information Management, and subsequently deposited in the University Library. Should any participant wish to withdraw from the project, they may do so until October $1^{\text {st }} 2013$ and the data collected up to that point will be destroyed. All data collected from participants will be destroyed within 2 years after the completion of the project.

A summary of the report will be sent to all participants upon the completion of the research, with the option to also have a copy for the full report if requested.

If you have any questions or would like to receive further information about the project, please contact me at clephasusa@myvuw.ac.nz or telephone 021057 3251, or you may contact my supervisor Dr Philip Calvert, Senior Lecturer School of Information Management at philip.calvert@vuw.ac.nz or telephone 463-6629 
Appendix B:

SCHOOL OF INFORMATION MANAGEMENT

TE KURA TIAKI, WHAKAWHITI KŌRERO

LEVEL 5, RUTHERFORD HOUSE, PIPITEA CAMPUS, 23 LAMBTON QUAY, WELLINGTON

PO Box 600, Wellington 6140, New Zealand

Phone +64-4-4635103 Fax +64-4-4635446 Email sim@vuw.ac.nz Website www.victoria.ac.nz/sim

\section{Participant Consent Form}

\section{Research Project Title: New Zealand School Libraries Uptake of High Speed Internet}

\section{Researcher: Suzy Clephane, School of Information Management, Victoria University of Wellington}

I have been given and have understood an explanation of this research project. I have had an opportunity to ask questions and have them answered to my satisfaction.

I understand that I may withdraw myself (or any information I have provided) from this project, without having to give reasons, by e-mailing clephasusa@myvuw.ac.nz by October the $1^{\text {st }} 2013$.

I understand that any information I provide will be kept confidential to the researcher and their supervisor, the published results will not use my name, and that no opinions will be attributed to me in any way that will identify me or school.

I understand that the data I provide will not be used for any other purpose or released to others.

I understand that, if this interview is audio recorded, the recording and transcripts of the interviews will be erased within 2 years after the conclusion of the project. Furthermore, I will have an opportunity to check the transcripts of the interview.

Please indicate (by ticking the boxes below) which of the following apply:

I would like to receive a summary of the results of this research when it is completed.

I agree to this interview being audio recorded.

Signed:

Name of participant:

Date: 
Appendix C - Email to Principal:

To

My name is Suzy Clephane, and I am currently a student at Victoria University of Wellington, studying towards my Masters of Information Studies.

I am writing to you today as part of my final research project - Investigating New Zealand school librarians, and the role they play as technology leaders in schools. This email is to request permission from you, for me to ask one of your librarians to participate in this study.

Participants will be asked to take part in a 30-60min interview. Permission will be asked of them to record the interview, and a transcript of the interview will be sent to participants for checking. Participation is voluntary and all material collected will be kept confidential, and will be viewed only by myself and my supervisor Dr Philip Calvert, Senior Lecturer School of Information Management.

I hope to benefit both current and future school communities through my research by promoting awareness of how to best use and support school librarians as technology communicators within schools. I aim to identify what the current situation is in schools where high speed internet is relatively new to both the staff and students, and what is being done to educate and promote the new capabilities high speed internet provides.

If you are willing to grant me access to your librarian/s or if you have any questions about the project, please contact me at clephasusa@myvuw.ac.nz or telephone 021057 3251, or you may contact my supervisor Dr Philip Calvert, Senior Lecturer School of mation Management at philip.calvert@vuw.ac.nz or telephone 463-6629

Sincerely

Suzy Clephane

Victoria University of Wellington MIS - Library Research Study Request 
Appendix D

\begin{tabular}{|l|l|l|l|}
\hline & Co-ed & All Boys & All Girls \\
\hline Gender & 4 & 3 & 1 \\
\hline
\end{tabular}

\begin{tabular}{|l|l|l|l|l|l|l|l|l|l|l|}
\hline & 1 & 2 & 3 & 4 & 5 & 6 & 7 & 8 & 9 & 10 \\
\hline Decile & 1 & - & - & 1 & - & - & - & - & 3 & 3 \\
\hline
\end{tabular}

\begin{tabular}{|l|l|l|l|}
\hline & $500-1000$ & $1001-2000$ & $2000+$ \\
\hline \# of students & 3 & 1 & 4 \\
\hline
\end{tabular}

Appendix E

The directory of schools will be found at http://www.educationcounts.govt.nz/directories/list-ofnz-schools (NZ Schools, 2013)

Word Count: 12,113

Susan Clephane

300272173 